\title{
Asesmen Kreativitas Dan Keberbakatan Anak
}

\author{
Navila Ngabito, Yenti Juniarti \\ Jurusan PG-PAUD Universitas Negeri Gorontalo \\ venti.juniarti@gmail.com
}

\begin{tabular}{l} 
Info Artikel \\
\hline Sejarah Artikel: \\
Diterima (April) (2019) \\
Disetujui (Mei) (2019) \\
Dipublikasikan (Juli) (2019) \\
\hline Keywords: \\
\hline
\end{tabular}

Assessment; creativity; giftedne

\begin{abstract}
Abstrak
Penelitian ini didasarkan atas suatu penilaian dari berbagai sistematika yang mendasari pada pembahasan mengenai kreativitas dan keberbakatan anak yang nantinya akan dikembangkan dalam menganalisis berbagai minat dan bakat yang terjadi pada anak. Kreativitas itu sendiri menjadikan suatu kompeten pada penilaian nantinya yang berkaitan dengan keberbakatan anak. Tujuan penelitian ini untuk mengetahui bagaimanan perkembangan kreativitas dan keberbakatan anak yang ada di PAUD Asmaul Husna. Pada saat penelitian dilakuakn dengan cara menganalisis proses pembelajaran anak. Metode yang digunakan dalam penelitian ini menggunakan metode penelitian kualitatif. Metode kualitatif adalah metode yang digunakan dari hasil pengamatan suatu objek. Peneliti melihat proses pembelajaran kreativitas dan keberbakatan di PAUD Asmaul Husna tingkat pencapaiannya masih kurang, sarana dan prasarana kurang memadai. Keberbakatan dan kreativitas di PAUD Asmaul Husna perlu dikembangkan berdasarkan hasil dari solusi yang peneliti buat sehingganya dapat di jadikan sebuah pengembangan untuk kegiatan aspek yang berkaitan dengan kreativitas keberbakatan anak khususnya di PAUD Asmaul Husna.
\end{abstract}

\begin{abstract}
This research is based on an assessment of various systematic that underlies the discussion of children's creativity and giftedness which will be developed in analyzing various interests and talents that occur in children. Creativity itself makes a competent in the assessment related to children's giftedness later. The purpose of this study was to determine how the development of creativity and giftedness of children in PAUD Asmaul Husna. At the time of the study conducted by analyzing the learning process of children. The method used in this study uses qualitative research methods. Qualitative method is a method used from the observation of an object. Researchers see the learning process of creativity and giftedness in Asmaul Husna PAUD is still lacking in level of achievement, inadequate facilities and infrastructure. Talent and creativity in PAUD Asmaul Husna need to be developed based on the results of the solution that researchers made so that it can be made as a development for aspects of activities related to children's gifted creativity especially in PAUD Asmaul Husna.
\end{abstract}




\section{Pendahuluan}

Menurut (Overtun, 2008), asesmen merupakan suatu pengumpulan data informasi agar dapat memonitoring kemajuan, serta disebutkan juga dalam definisi tentang berbagai tes. Dan asesmen juga terdiri dari beberapa tes, serta terdiri dari berbagai metode yang seperti mengopservasi, mewawancara, dan menganalisis berbagai data.

Merujuk pada hasil penelitian menurut (Munandar, 1983), mendefinisikan bahwa "Kreativitas merupakan kemampuan yang dapat menciptakan sesuatu hal-hal yang baru". Kemampuan ini yang memungkinkan kita sebagai individu kreatif agar dapat merubah dan memperkaya dunia. Dengan penemuan-penemuan diberbagai bidang ilmu, baik dalam bidang teknologi, seni maupun dalam bidang-bidang lainnya, yang merupakan hasil ciptaan individu kreatif.

Menurut (Santrock, 2011), mendefinisikan bahwa kreativitas adalah suatu kemampuan digunakan untuk memikirkab sebuah sesuatu hal atau cara yang baru. Serta hal ini juga dapat melahirkan banyak sekali solusi yang sangat unik, dan dapat menyelesaikan berbagai masalah-masalah yang dihadapi dalam mengembangkan kreativitas. Serta mengembangkan berbagai kreasi yang dapat mewujudkan cita-cita, hal ini dapat memotivasi diri dan mendorong timbulnya sebuah kreativitas yang unik. Dengan ini kreativitas juga dapat menghasilkan sesuatu produk yang menarik dan unik, serta tidak bergantung dari orang-orang yang ada disekitar dengan dalam arti memuaskan diri sendiri, bukan berarti dikeranakan mendapat berbagai tekana dari luar. Sehingga dari semua ini dapat mnemukan cara ataupun ide baru yang tidak pernah ditemukan orang lain

Menurut (Judarwanto, 2007), mendefinisikan keberbakatan merupakan suatu kemampuan secara intelektual atau kecerdasan. Dimana meliputi kemapuan dalam bidang pengetahuan ataupun dalam bidang seni. Dimana tingkat kemampuan bakat ini diatas rata-rata anak seusianya.

Menurut (Galton, 2002), mendefinisikan keberbakatan adalah suatu kemampuan yang sudah dimiliki secara alami yang sangat luar biasa, yang diperoleh dari baebagai kombinasi yang memiliki sifat-sifat meliputi kamauan yang kuat, intelektual, serta unjuk kerja. 


\section{Metode Penelitian}

Metode penelitian yang gunakan yaitu metode kualitatif. Istilah penelitian kualitatif menurut (Krik \& Miller, 1988), mendefinisikan bahwa pada mulanya bersumber pada pengamatan kualitatif dimana dipertentangkan dengan penelitian kuantitatif. Sehingga mereka mendefinisikan bahwa metodologi kualitatif merupakan suatu tradisi tertentu yang didalamnya terdapat ilmu pengetahuan sosial. Yang secara fundamental bergantung pada suatu pengamatan manusia, yang dalam bentuk kaasannya sendiri dan berhubungan langsung dengan orang-orang tersebut dalam bahasanya maupun dalam peristilahannya. Penelitian kualitatif ini memiliki suatu ciriciri atau karakteristik yang dapat membedakan dengan penelitian-penelitian lainnya.

Jenis Penelitian

Penelitian ini menggunakan pendekatan kualitatif, dimana peneliti menganalisis data dengan cara mendeskripsikan.

Waktu dan Tempat Penelitian

Peneliti melakukan penelitian ini pada tanggal 22 oktober 2019 sampai tanggal 22 november 2019, bertempat di PAUD Asmaul Husna, Jln. Rusli Datau. Blok. A9. Kec. Kota Utara, Gorontalo.

Subjek Penelitian

Subjek penelitian yang diteliti ini adalah anak-anak yang berada di PAUD Asmaul Husna, pada kelas TK kelompok A. Dengan berjumlah 8 anak, dengan anak laki-laki berjumlah 4 dan anak perempuan bejumlah 4 anak.

Data, Intrumen, dan Teknik Pengumpulan Data

Penelitian ini dilakukan dengan cara meneli aktivitas yang dilakukan anak dalam mengembangkan kreativitas dan keberbakatan anak di PAUD Asmaul Husna dijenjang TK kelompok.

\section{Hasil Penelitian dan Diskusi}

Adapun Peneliti mengangkat suatu masalah dari PAUD Asmaul Husna ini dimana kreativitas yang terjadi di PAUD tersebut terkhusus pada Anak usia Dini yang mengalami keterlambatan terhadap kreativitas dikarenakan kurangnya prasarana dan penunjang pembelajaran yang berhubungan dengan keberbakatan seorang anak. 
Sehingganya peneliti mengangkat sebuah permasalahan ini kemudian dijadikan solusi dari berbagai aspek dan cara pengembangan kretaivitas di PAUD Asmaul Husna.

Pada saat meneliti, peneliti malakukan penelitian di PAUD Asmaul Husna. Peneliti meneliti anak yang berada di jenjang TK, kelompok A. Dengan jumlah anak sebanyak 8 orang, dimana anak laki-laki berjumlah 4 orang dan anak perempuan berjumlah 4 orang juga. Disini peneliti ingin menilai apakah di PAUD Asmaul Husna ini tingkat kreativitas dan keberbakan pada anak usia dini pada jenjang TK kelompok A ini sudah sangat berkembang atau masih perlu lagi ditingkatkan dalam proses pembelajarannya.

Dan pada saat proses pembelajaran dimulai, peneliti mengamati proses pembelajaran peserta didik dari awal samapi akhir pembelajaran. Sebelum kegiatan pembelajaran peserta didik dimulai, guru memberikan kegiatan baris berbaris, dimana didalam kegiatan baris berbaris ini, guru membimbing anak-anak untuk membaca doa sebelum masuk kelas bersama-sama. Setelah selesai membaca doa bersama sama, guru membimbing anak-anak masuk di dalam kelas secara teratur, di dalam kelas guru mulai memulai kegiatan dengan membaca doa belajar, selesai membaca doa, guru mulai menyampaikan kegiatan atau tema apa yang akan dilakukan pada pembelajaran hari ini. Selepas melakukan kegiatan pembelajaran peneliti mengamati setiap aktivitas yang peserta didik lakukan hal ini berkaitan dengan pengembangan kreativitas dan bakat peserta didik di PAUD Asmaul Husna khususnya di jenjang TK kelompok A.

Dapat dilihat pada pembelajaran kreativitas dan keberbakatan di PAUD Asmaul Husna ini dijenjang TK kelompok A, dimana bahwasanya tingkat kreativitas dan keberbakatan anak masih kurang, serta sarana dan prasarana untuk menunjang kreativitas dan keberbakatan anak masih kurang memadai atau masih perlu ditingkatkan lagi. Peneliti dapat menganalisis setiap sampel yang ditemukan kemudian di data satu persatu yang nantinya dikaitkan dengan hasil penelitian orang lain yang mencantumkan beberapa teori yang berpengaruh pada penilaian kreativitas dan keberbakatan peserta didik di PAUD Asmaul Husna.

Adapun merujuk pada hasil penelitian menurut (Harlock, 2010), kreativita merupakan salah satu proses yang dapat menghasilkan sesuatu yang baru. Dalam hal ini berupa bentuk atau susunan baru. 
Adapun merujuk pada hasil penelitian menurut (Alvian, 2010), kreativitas merupakan proses upaya manusia ataupun bangsa dalam membangun diri dari berbagai aspek kehidupan dengan bertujuan menikmati semua kualitas kehidupan yang semakin baik.

Adapun merujuk pada hasil penelitian menurut (Renzulli, 2002), keberbakatan adalah salah satu interaksi antara kemampuan umum atau khusus. Dimana tingkat tanggung jawab terhadap semua tugas yang tingkat kreativitasnya tinggi.

Adapun merujuk pada penelitian menurut (Clark, 1986), dimana keberbakatan merupakan suatu ciri-ciri yang sangatmenyeluruh dan sangat khusus maupun luar biasa. Hal ini dibawa dari sejak lahir, dan juga merupakan salah satu hasil interaksi yang berpengaruh terhadap lingkungan.

Adapun merujuk pada hasil penelitian menurut (Lubard, 1994; Ochse, 1990; Sternberg, 1988; Sternberg \& Lubard, 1996), Kreativitas dan keberbakatan secara konseptual ditinjau dari berbagai segi. Dan pengertian kreativitas merupakan salah satu hal yang memiliki perspektif baru. Dimana hal ini bersifat orisinil, dan tak terduga, berguna, serta adaptif terhadap segala kendala-kendala tugas yang ada. Merujuk pada hasil penelitian menurut (Semiawan, 2010), Kreativitas memiliki cakupan yang luas dan penting bagi individu serta masyarakat. Hal ini berkaitan dengan individu dengan rentangan yang luas dalam cakupan berbagai tugas, misalnya kreativitas yang relevan dalam mengatasi segala masalah yang berkenaan dengan tugas-tugas manusia.

Pada tingkat masyarakat, kreativitas merupakan sesuatu yang dapat menghasilkan ilmu baru. Dan merupakan gerakan baru dalam bidang seni, maupun perubahan budaya, serta program social yang baru dalam bidang ekonomi. Kreativitas juga menghasilkan suatu produk baru dan memungkinkan juga lowongan kerja baru. Pentingnya kreativitas pada suatu organisasi yaitu, individu maupun masyarakat lainnya harus menyesuaikan sumber yang ada agar merubah tugas utama tetap menantang.

Menurut (Clark, 1969), dari berbagai hasil penelitian telah menunjukkan berbagai kriteria tentang kreativitas dan keberbakatan., Seperti yang dikatakan, tidak ada satu kriteria tunggal yang mununjukkan konsep kreativitas ataupun konsep kreativitas dan keberbakatan yang lengkap. Penelitian ini dilakukan pada berbagai 
pribadi yang unik, dan telah menyelesaikan berbagai karya serta sudah memperoleh pengakuan internasional.

Hasil akhir aktivitas di PAUD Asmaul Husna di jenjang TK kelompok A ini, yaitu peneliti mengaitkan kegiatan pembelajaran dengan kreativitas dan keberbakatan anak. Sehingga peneliti membuat sebuah format penilaian dalam bentuk tabel penilaian. Dari format penilaian ini, peneliti lebih mudah mengambil sampel yang kemudian setiap data-data dapat dianalisis dengan mencantumkan hasil penelitian di PAUD Asmaul Husna jenjang TK kelompok A, dengan hasil penelitian orang lain atau merujuk pada hasil teori yang di temukan.

\section{Tabel Penilaian Kreativitas dan Keberbakatan Anak}

\begin{tabular}{ll}
\hline No. & \multicolumn{1}{c}{ Indikator } \\
\hline 1. & Anak dapat membuat lipatan kertas dengan \\
& bahan dasar origami. \\
2. & Anak dapat menggunting dan membentuk lipatan \\
& kertas \\
3. & Anak dapat mewarnai gambar dengan rapi dan \\
\hline 4. & anak dapat mendaur ulang sampah plastic \\
& manjadi 1 kreativitas yang unik \\
\hline 5. & Anak dapat membuat slime dengan bahan dasar \\
\hline
\end{tabular}

Adapun solusi yang dapat diberikan oleh peneliti dalam meningkatkan kreativitas dan keberbakatan anak, di PAUD Asmaul Husna di jenjang TK Kelompok A, sebagai berikut:

\section{Selalu Berfikir Positif}

Selalu memancing kreativitas dan keberbakatan anak, maka seringlah berfikir positif, dengan selalu berfikir positif maka kreativitas dan keberbakatan anak dapat semakin meningkat. 


\section{Jangan Memaksa Anak}

Jika memaksa, dapat menimbulkan rasa stress pada anak dan juga dapat menyebabkan jalan kreativitas dan bakat mereka akan terhambat. Juga dapat membunuh daya imajinasi dan ide anak yang ingin dikembangkan.

\section{Mengembangkan Imajinasi Anak}

Membiarkan anak dalam mengembangkan imajinasi mereka, serta memberikan permainan edukatif yang dapat membebaskan anak dalam membangun dan membentuk sesuatu sesuai dengan keinginan anak. Dengan hal ini imajinasi anak dapat bekerja dengan baik.

\section{Mengasah Minat dan Bakat Anak}

Salah satu cara yang dapat dilakukan dalam mengasah minat dan bakat anak yaitu dengan cara menstimulasi anak terlebih dahulu, dan juga bisa melalui tes minat dan bakat, serta mengikuti kegiatan-kegiatan ekstrakulikuler yang dapat mengasah minat dan bakat pada anak.

\section{Meberikan Tantangan yang Menarik}

Melalui pemberian tantangan ini, dapat memberikan pengalaman yang baru pada anak, juga dapat meningkatkan kreativitas dan bakat anak menjadi lebih baik.

\section{Sering Memberi Pujian Pada Anak}

Memberi pujian pada anak, dapat meningkatkan rasa percaya diri anak. Dari pujian ini juga anak akan menghasilkan sebuah karya-karya yang sangat luar biasa, serta dapat membangun kkreativitas dan keberbakatan anak menjadi lebih baik lagi.

\section{Menumbuhkan Rasa Tanggung Jawab}

Membiarkan anak dalam mencari solusi sendiri atas apa yang telah mereka lakukan, serta membiarkan mereka dalam mengembangkan pikirannya sendiri.

\section{Pahami Anak}

Jangan pernah menyamakan ataupun membandingkan anak dengan anak yang lain, setiap anak mempunyai kel;ebihan dan kekurangan masing-masing, termasuk kreavitas atau bakatnya. dan seringlah mencari hal-hal yang dapat menumbuhkan 
kreativitas anak dengan baik, tanpa harus mengganggu ataupun merusak perkembangan kreativitas dan keberbakatan anak.

Sehingga peneliti berharap solusi ini dapat meningkatkan kraetivitas dan keberbakatan pada PAUD Asmaul Husna dijenjang TK Kelompok A.

\section{SIMPULAN}

Kesimpulan peneliti dari penelitian ini ialah kreativitas dan keberbakatan merupakan kemampuan-kemampuan yang unggul serta mampu memberikan prestasi yang tinggi. Adapun mengenai hal keberbakatan dan kreativitas di PAUD Asmaul Husna perlu dikembangkan berdasarkan hasil dari solusi yang peneliti buat sehingganya dapat di jadikan sebuah pengembangan untuk kegiatan serta aspek yang berkaitan dengan kreativitas keberbakatan anak khususnya di PAUD Asmaul Husna.

\section{DAFTAR PUSTAKA}

Ismi ranjani (2015). Kreativitas dan Keberbakatan. Diakses 12 tanggal Desember 2019 dari http://ismiranjani.blogspot.com/2015/05/kreativitas-dankeberbakatan.html?m=1

Dosenpsikologi. 14 Cara Meningkatkan Kreativitas pada Anak yang Wajib Diketahui. $\begin{array}{lllll}\text { Diakses } & \text { tanggal } & 13 & \text { Desember } & 2019\end{array}$ https://www.google.com/amp/s/dosenpsikologi.com/cara-meningkatkankreativitas-pada-anak/amp

Ganil Nurmala, Wantu Tuti, Ardini Pupung Puspa. Identifikasi Kesadaran Diri pada Anak di TK Negeri Pembina Pohuwato. https://ejournalfipung.ac.id/ojs/index.php/jecej/article/view/50

Pengetahuan Seputar (2017). 17 Pengertian Assessment Menurut Para Ahli (Pembahasan $\begin{array}{llllll}\text { Lengkap). } & \text { Diakses } & \text { tanggal } & 17 & \text { Desember } & 2019\end{array}$ https://www.seputarpengetahuan.co.id/2017/09/pengetian-assessment-menurutpara-ahli.html 
Rahma Saeful Pupu (2009). Penelitian Kualitatif. EQUILIBRIUM, Volume 5, No. 9 Tahun 2009.

Rohani, S.Ag, M.Pd (2017). Meningkatkan Kreativitas Anak Usia Dini Melalui Media Bahan Bekas. Jurnal Tarbiyah Vol 5, No. 022017 A'yuna Qurrata (2015). Konstribusi Peran Orangtua dan Guru Mata Pelajaran Terhadap Pengembangan Kreativitas Siswa. Jurnal Ilmiah Edukasi Vol 1, No. 12015

Semiawan R. Conny. Cetakan Ketiga (2010). Kreativitas Keberbakatan: Mengapa, Apa, dan Bagaimana. Jakarta 